\title{
Aktivitas Residu Protein Cry1Ac Pada Lahan yang Ditanami Kapas Transgenik-Bt di Bajeng dan Soppeng, Sulawesi Selatan
}

\author{
PURNAMA HIDAYAT DAN D. PRIJONO \\ Departemen Proteksi Tanaman, Fakultas Pertanian, Institut Pertanian Bogor \\ Jl. Kamper, Kampus Darmaga, IPB, Bogor \\ (diterima July 2005, disetujui September 2005)
}

\begin{abstract}
The persistence in soil of Cry1Ac protein originating from transgenic Bt-cotton was determined using bioassay against the cotton bollworm, Helicoverpa armigera (Hubner) (Lepidoptera: Noctuidae). Transgenic Bt-cotton (Bollgard) and nontransgenic cotton (Delta Pine) were planted at two field sites in South Sulawesi, i.e. in Bajeng and Sopeng. Soil samples were collected from each plot at the two field sites at $0,1,3$, and 5 months after planting, and at one-month intervals after harvest for three months. Soil suspension from each sample was mixed with agar based diet $(1 \mathrm{~g}$ soil $/ 20 \mathrm{ml}$ soil-diet mixture) then was presented to neonate larvae of $H$. armigera. Two reference standards were used, i.e. pure Cry1 Ac protein $\left(0.165 \times 10^{4}\right.$ to $1.436 \times 10^{5} \mathrm{ng}$ per $\mathrm{ml}$ of the proteindiet mixture) and non-Bt-soil spiked with Cry1Ac protein (0.11 x $10^{4}$ to $9.573 \times 10^{4} \mathrm{ng}$ per $\mathrm{ml}$ of the soil-diet-mixture). Larval mortality was recorded at 7 days of treatment. In both reference standards, mortality of $H$. armigera larvae occurred in a concentrationdependent fashion, i.e. larval mortality increased with the increase in Cry1Ac protein concentration, with $\mathrm{LC}_{50}$ of $0.95 \times 10^{4}$ and $1.65 \times 10^{4} \mathrm{ng} / \mathrm{ml}$, respectively, for the pure protein and spiked non-Bt-soil standards. Result of the bioassay of soil samples from the field sites showed the residues from both transgenic cotton soils did not cause any mortality $(0 \%)$ in the test insects. This indicates that the concentrations of Cry1Ac residue in soil at the study sites were very low (in the second standard, Cry1Ac at a concentration of $0.33 \times 10^{4} \mathrm{ng} / \mathrm{ml}$ caused about $10 \%$ larval mortality).
\end{abstract}

KEY WORDS: Transgenic-Bt, Cry1AC, Kapas, Sulawesi Selatan, Helicoverpa armigera

\section{PENDAHULUAN}

Permintaan bahan baku pakaian yang semakin meningkat akibat meningkatnya penduduk dunia menuntut peningkatan produksi kapas. Namun, budidaya kapas secara monokultur dalam areal yang luas mengandung risiko mengalami serangan hama yang berat. Pada kenyataannya, kapas selalu diserang oleh berbagai jenis hama setiap musim tanam dan petani kapas selalu menggunakan insektisida untuk mengendalikan hama-hama tersebut.

$$
\text { Sejarah telah membuktikan }
$$
bahwa penggunaan insektisida yang berlebihan pada budi daya kapas dapat mengakibatkan kebangkrutan usaha pertanian kapas sebagaimana yang terjadi di Meksiko pada akhir tahun 1960-an. Di pusat produksi kapas Lembah Rio Grande Bawah di bagian timur laut Meksiko, sebelum tahun 
1960-an ulat Heliothis zea dan $H$. virescens merupakan hama sekunder pada tanaman kapas. Akibat penggunaan insektisida yang terusmenerus terhadap hama utama kapas ketika itu, yaitu kumbang moncong Anthonomus grandis, kedua spesies ulat Heliothis tersebut berkembang menjadi hama utama kapas sejak tahun 1962. Berhubung pengen dalian alamiah tidak memadai, petani kapas di daerah tersebut selalu menggunakan insektisida dan akibatnya kedua spesies Heliothis tersebut makin lama makin resisten terhadap insektisida yang digunakan. Pada tahun 1969, H. virescens telah resisten terhadap semua golongan insektisida sintetik yang tersedia, dan akhirnya pada tahun 1970 petani kapas di daerah tersebut menutup usaha pertanian kapas mereka karena sudah tidak menguntungkan lagi (Metcalf 1982).

$$
\text { Meskipun Bt memiliki }
$$
keunggulan sifat yang sesuai dengan konsep pengendalian hama terpadu (PHT) dan sering dimanfaatkan dalam program pengelolaan resistensi terhadap insek tisida sintetik, pengembangan insektisida $B t$ dalam skala yang lebih luas terkendala oleh beberapa kelemahan, seperti kisaran inangnya yang relatif sempit, harus termakan untuk dapat membunuh hama sasaran, tidak efektif untuk hama penggerek atau pengorok, cepat mengalami inaktivasi oleh cahaya matahari, toksin Bt cepat terdegradasi di dalam tanah oleh mikroorganisme, mudah terjerap pada bahan organik tanah (Possee \& King 1994). Selain itu keefektifan Bt juga dipengaruhi oleh waktu penyemprotan, liputan semprotan, perilaku makan larva, dan daya tahan formulasi terhadap siraman air hujan (Baum et al. 1994).

Pemahaman segi genetika produksi protein Cry dan perkembangan rekayasa genetika memungkinkan orang untuk mentransfer gen yang mengkode sintesis protein Cry ke tanaman sehingga jaringan tanaman dapat memproduksi toksin $B t$ tersebut dan beracun bagi serangga yang memakannya. Protein Cry yang terdapat di dalam jaringan tanaman akan terlindung dari cahaya matahari dan faktor-faktor lingkungan lain yang dapat mendegradasi protein tersebut.

Tanaman kapas transgenik didaftarkan pertama kali pada EPA (Environmental Protection Agency) Amerika Serikat (AS) pada bulan Oktober 1995, yaitu kapas transgenik yang mengekspresikan gen $\delta$ endotoksin dari Bt kurstaki yang mengkode protein Cry1Ac (Jenkins 1999). Hama sasaran utama kapas transgenik CryaAc antara lain ulat Heliothis virescens (di AS) dan Helicoverpa armigera (di luar AS) (Fitt \& Wilson 2000). Kapas-Bt telah menjadi salah satu komponen PHT kapas. Pada tahun 1997, penanaman kapas-Bt Bollgard (Monsanto) di AS dapat mengurangi penggunaan insektisida 
sintetik sebanyak 1,2 juta liter (Sherrick \& Head 2000).

Sejumlah persyaratan harus di penuhi dalam proses pendaftaran kapas-Bt pada instansi yang berwenang (Departemen Pertanian RI), di antaranya ialah persistensi di residu toksin Bt yang dihasilkan oleh kapas transgenik dalam tanah sebagai salah satu indikator dari keamanan penanaman kapas transgenik bagi lingkungan.

Percobaan ini bertujuan mengetahui persistensi protein Cry1Ac di dalam tanah dengan cara menguji aktivitas residu tanah yang ditanami kapas transgenik-Bt Bollgard terhadap ulat kapas Helicoverpa armigera.

\section{BAHAN DAN METODE}

\section{Cara Pengambilan Contoh Tanah}

Kapas transgenik-Bt (Bollgard) dan kapas nontransgenik (Delta Pine) sebagai pembanding ditanam di dua tempat di Sulawesi Selatan, yaitu Bajeng dan Soppeng. Di kedua tempat tersebut, kapas Bollgard dan Delta Pine masing-masing ditanam pada tiga dan empat petak. Contoh tanah diambil dari setiap petak di kedua tempat tersebut pada $0,1,3$, dan 5 bulan setelah tanam, serta pada 1, 2, dan 3 bulan setelah panen. Untuk setiap kali pengambilan contoh tanah, 3 contoh silinder tanah, masingmasing dengan tinggi 15,24 cm (6 inci) dan diameter 7,62 cm (3 inci), diambil secara acak dari barisan tengah tanaman dari setiap petak kapas Bollgard dan Delta Pine. Semua contoh tanah di masukkan dalam kotak pendingin dengan es kering ( $d r y$ ice) dan disimpan pada suhu $-20{ }^{\circ} \mathrm{C}$ sampai saat diuji aktivitas residunya.

\section{Pengujian Aktivitas Residu CryAc dalam Tanah.}

Untuk menguji aktivitas residu protein Cry1Ac dalam tanah, contoh tanah dari petak kapas Bollgard dan Delta Pine dicampurkan ke dalam makanan buatan larva Helicoverpa armigera (Lampiran 1), kemudian diberikan pada larva instar 1 serangga tersebut. Satu setengah gram tanah dari setiap contoh dimasuk kan ke dalam tabung reaksi kaca (diameter 1,5 $\mathrm{cm}$ dan tinggi $15 \mathrm{~cm})$, lalu ditambahkan $6 \mathrm{ml}$ air dan dikocok secara seksama menggunakan pengocok vor teks, dan selanjutnya campuran disaring dengan kain chifon. Empat $\mathrm{ml}$ suspensi tanah dipindahkan ke tabung sentrifusa polipropilen 50 $\mathrm{ml}$, lalu ditambahkan makanan buatan larva $H$. armigera sampai volume akhir mencapai $20 \mathrm{ml}$, dan selanjutnya campuran tersebut dikocok secara seksama. Kira-kira 1 g campuran tanah-makanan dimasukkan ke dalam tabung plastik dengan diameter $2 \mathrm{~cm}$ dan tinggi $4 \mathrm{~cm}$. Setelah campuran tanah-makanan dingin dan mengeras, satu ekor larva instar $1 H$. armigera di letakkan dalam setiap tabung, kemudian disimpan dalam ruang pemeliharaan pada suhu $27{ }^{\circ} \mathrm{C}$ selama 
7 hari. Setelah 7 hari pemaparan, mortalitas larva $H$. armigera dihitung.

Dalam percobaan ini digunakan dua macam standar acuan. Untuk standar pertama, 9 taraf konsentrasi Cry1Ac disiapkan dengan cara mencampurkan $3,3 \times 10^{4}$ sampai 2,872 x $10^{6}$ ng Cry1Ac dalam $4 \mathrm{ml}$ air dengan makanan buatan sehingga volume akhir campuran mencapai 20 ml. Konsentrasi akhir Cry1Ac dalam campuran protein-makanan berkisar dari $0,165 \times 10^{4}$ sampai $1,436 \times 10^{5} \mathrm{ng}$ per $\mathrm{ml}$ campuran. Standar kedua disiapkan dengan menambahkan larutan Cry1Ac dengan berbagai konsentrasi pada contoh tanah nonBt. Satu setengah gram tanah nonBt dicampur secara merata dengan 3,3 $\mathrm{x}$ $10^{4}$ sampai $2,872 \times 10^{6} \mathrm{ng}$ Cry 1 Ac dalam $6 \mathrm{ml}$ air, kemudian disaring dengan kain chifon. Empat $\mathrm{ml}$ suspensi tanah saringan kemudian dicampur dengan makanan buatan sampai volume akhir campuran mencapai $20 \mathrm{ml}$. Konsentrasi akhir Cry1Ac dalam campuran tanahmakanan berkisar dari $0,11 \times 10^{4}$ sampai $9,573 \times 10^{4}$ ng per $\mathrm{ml}$ campuran. Campuran makanan untuk kedua standar tersebut diuji terhadap larva $H$. armigera dengan cara seperti pada pengujian aktivitas residu contoh tanah dari la pangan. Tanah nonBt yang diambil dari lokasi yang sama dan tidak diperkaya dengan protein Cry1Ac digunakan sebagai kontrol negatif. Mortalitas larva $H$. armigera akibat perlakuan dengan kedua macam standar tersebut diolah dengan analisis probit (Finney 1971) menggunakan paket program statistika SAS (SAS Institute 1990).

\section{Penyiapan Makanan Buatan Larva Helicoverpa armigera (Diadaptasi dari Moore (1985), Patana (1985), dan Singh (1985)}

Komposisi makanan buatan untuk larva $H$. armigera adalah sebagai berikut (untuk setiap $1600 \mathrm{ml}$ air): kacang merah $125 \mathrm{~g}$, agar $24 \mathrm{~g}$, kasein $50 \mathrm{~g}$, wheat germ $100 \mathrm{~g}$, khamir 62,5 g, asam askorbat $6 \mathrm{~g}$, asam sorbat $3 \mathrm{~g}$, metil paraben $5 \mathrm{~g}$, campuran vitamin Vanderzant $10 \mathrm{~g}$, dan tetrasiklin 0,125g.

Makanan buatan tersebut dibuat dengan cara sebagai berikut: kacang merah (125 g) direndam dalam air selama satu malam, ditiriskan, kemudian digiling dalam $1000 \mathrm{ml}$ air dengan menggunakan blender. Secara terpisah, pada agar (24 g) dalam panci nirkarat ditambahkan $600 \mathrm{ml}$ air, kemudian dipanaskan pada suhu $95^{\circ} \mathrm{C}$ dengan menggunakan pembakar bunsen, dan selanjutnya agar cair yang di peroleh didinginkan sampai suhu 75 ${ }^{\circ} \mathrm{C}$. Wheat germ (100 g), khamir (62,5 $\mathrm{g})$, asam askorbat (6 g), asam sorbat (3 g), dan metil paraben (5 g) ditambahkan kedalam adonan kacang merah sambil di aduk secara merata, kemudian agar cair ditambahkan ke dalam campuran tersebut, diikuti campuran vitamin Vanderzant (10 g) dan tetrasiklin $(0,125 \mathrm{~g}), \quad$ dan 
selanjutnya campuran tersebut dikocok dengan mixer. Setelah dingin dan memadat, makanan buatan yang diperoleh disimpan dalam lemari es.

\section{HASIL DAN PEMBAHASAN}

Pada kedua standar acuan, mortalitas larva $H$. armigera terjadi mengikuti pola terpaut konsentrasi, yaitu mortalitas larva meningkat dengan semakin tinggi nya konsentrasi protein Cry1Ac. Dalam pengujian kedua macam standar tersebut, tidak ada larva kontrol yang mati (mortalitas larva kontrol 0\%). Pada standar pertama (protein Cry1Ac murni di campur langsung dengan makanan buatan), perlakuan dengan protein Cry1Ac pada kisaran konsentrasi 0,165 x $10^{4}$ sampai $14,36 \times 10^{4}$ ng per ml campuran makanan mengakibatkan mortalitas larva sekitar 12\% sampai 95\%, dan pada standar kedua (protein Cry1Ac murni dicampur dengan contoh tanah kemudian dicampur dengan makanan buatan),

Tabel 1. Mortalitas larva instar $1 \mathrm{H}$. armigera akibat perlakuan dengan protein Cry1Ac

\begin{tabular}{|c|c|c|c|}
\hline$J^{J e n i s ~ s t a n d a r}{ }^{a}$ & $\begin{array}{l}\text { Konsentrasi Cry1 Ac } \\
\left(10^{4} \mathrm{ng} / \mathrm{ml}\right)\end{array}$ & $\begin{array}{l}\text { Jumlah } \\
\text { serangga uji }\end{array}$ & $\begin{array}{c}\text { Mortalitas larva } \\
(\%)\end{array}$ \\
\hline \multirow[t]{10}{*}{ Standar 1} & 0 (kontrol) & 60 & 0 \\
\hline & 0,165 & 59 & 11,9 \\
\hline & 0,285 & 58 & 19,0 \\
\hline & 0,500 & 60 & 45,0 \\
\hline & 0,875 & 58 & 50,0 \\
\hline & 1,530 & 60 & 66,7 \\
\hline & 2,680 & 60 & 73,3 \\
\hline & 4,690 & 60 & 78,3 \\
\hline & 8,205 & 60 & 85,0 \\
\hline & 14,360 & 60 & 95,0 \\
\hline \multirow[t]{10}{*}{ Standar 2} & 0 (kontrol) & 60 & 0 \\
\hline & 0,110 & 60 & 0 \\
\hline & 0,190 & 60 & 0 \\
\hline & 0,333 & 57 & 10,5 \\
\hline & 0,583 & 60 & 25,0 \\
\hline & 1,020 & 58 & 39,7 \\
\hline & 1,787 & 60 & 50,0 \\
\hline & 3,127 & 60 & 60,0 \\
\hline & 5,470 & 60 & 85,0 \\
\hline & 9,573 & 60 & 91,7 \\
\hline
\end{tabular}

${ }^{a}$ Standar 1: Cry1Ac dicampur secara langsung dengan makanan buatan.

Standar 2: Cry1Ac dicampur dengan tanah, kemudian suspensi tanah saringan dicampur dengan makanan buatan.

Tabel 2. Hasil analisis probit data mortalitas larva $H$. armigera pada Tabel 1

\begin{tabular}{lcccc}
\hline \hline $\begin{array}{l}\text { Jenis } \\
\text { standar }\end{array}$ & $a \pm \mathrm{GB}^{\mathrm{a}}$ & $b \pm \mathrm{GB}^{\mathrm{a}}$ & $\begin{array}{c}\mathrm{LC}_{50}(\mathrm{SK} 95 \%)^{\mathrm{a}} \\
\left(10^{4} \mathrm{ng} / \mathrm{ml}\right)\end{array}$ & $\begin{array}{c}\mathrm{LC}_{95}(\mathrm{SK} 95 \%)^{\mathrm{b}} \\
\left(10^{4} \mathrm{ng} / \mathrm{ml}\right)\end{array}$ \\
\hline Standar 1 & $-5,21 \pm 0,45$ & $1,31 \pm 0,11$ & $0,946(0,752-1,169)$ & $17,0(11,3-29,6)$ \\
Standar 2 & $-7,17 \pm 0,68$ & $1,70 \pm 0,16$ & $1,648(1,365-1,982)$ & $15,3(10,5-25,9)$ \\
\hline
\end{tabular}

${ }^{a} a$ dan $b$ : penduga dari parameter regresi probit linier; GB: galat baku; SK: selang kepercayaan. 
perlakuan dengan Cry1Ac pada kisaran konsentrasi $0,333 \times 10^{4}$ sampai $9,573 \times 10^{4} \mathrm{ng}$ per $\mathrm{ml}$ campuran makanan menyebabkan mortalitas larva sebesar $10,5 \%$ sampai $91,7 \%$ (Tabel 1). Hasil analisis probit data pada Tabel 1 menghasilkan LC $_{50}$ Cry1Ac pada standar pertama dan kedua terhadap larva instar $1 H$. armigera masing-masing $0,946 \times 10^{4}$ dan 1,648 x $10^{4} \mathrm{ng} / \mathrm{ml}$ (Tabel 2). Lebih tingginya $\mathrm{LC}_{50}$ Cry1Ac pada standar kedua mungkin disebabkan oleh penjerapan sebagian protein Cry1Ac oleh partikel-partikel tanah sehingga protein Cry1Ac yang ditambahkan pada contoh tanah tidak seluruhnya terbawa dalam suspensi tanah saringan. Karena itu, Cry1Ac perlu ditambahkan pada contoh dengan konsentrasi yang lebih tinggi agar bisa memberikan tingkat mortalitas larva uji yang setara dengan perlakuan Cry1Ac yang dicampurkan langsung dengan makanan larva. Sementara itu, LC $_{95}$ Cry1Ac pada standar kedua lebih rendah daripada standar pertama, tetapi perbedaan tersebut tidak nyata (selang kepercayaan 95\% untuk $\mathrm{LC}_{95}$ kedua macam standar tersebut tumpangtindih, Tabel 2). Pada konsentrasi yang relatif tinggi, Cry1Ac mungkin dapat di ekstrak dengan air dari tanah dengan lebih mudah dibandingkan dengan pada konsentrasi rendah. $\mathrm{Hu}-$ bungan konsen trasimortalitas Cry1 Ac terhadap larva instar $1 \mathrm{H}$. armigera ditunjukkan pada Gambar 1. Semua residu contoh tanah dari petak yang ditanami kapas Bollgard (kapas-Bt) maupun Delta Pine (kapas-nonBt) di kedua lokasi percobaan (Bajeng dan Soppeng) tidak mengakibatkan mortalitas pada larva $H$. armigera (mortalitas 0\%, Tabel 3).

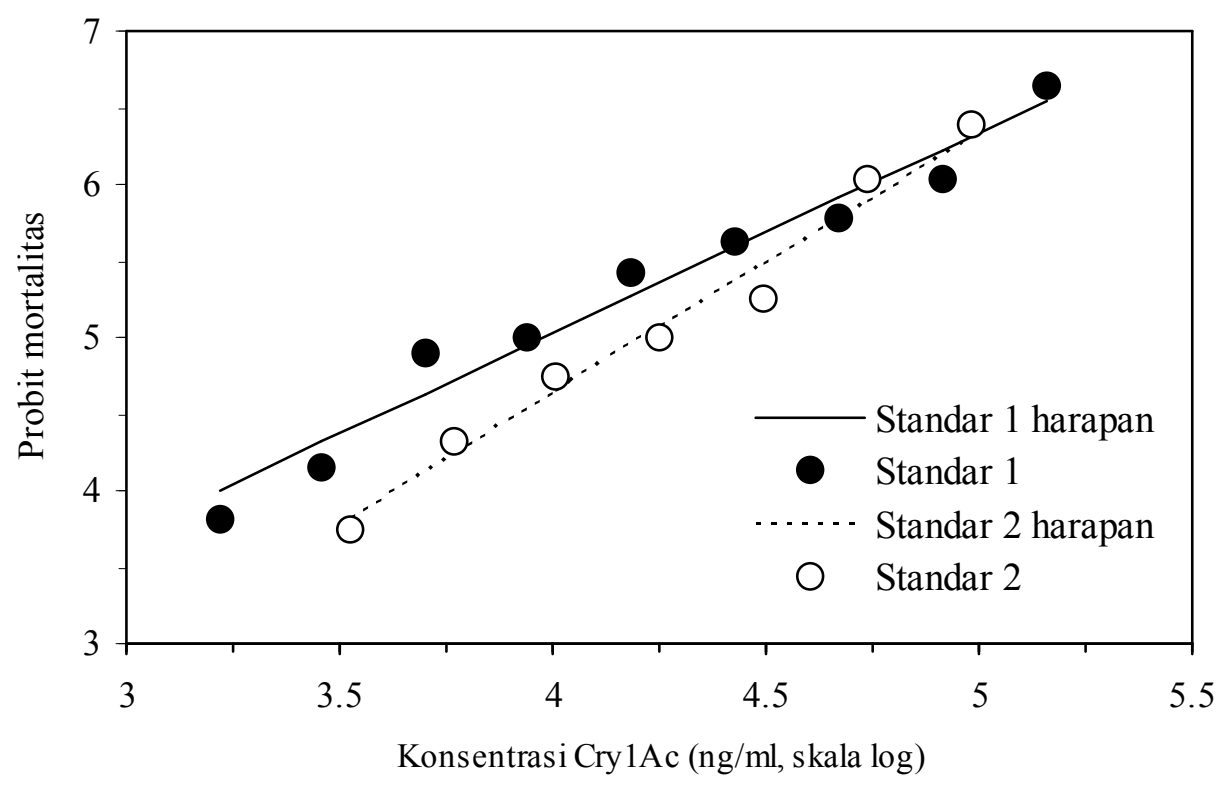

Gambar 1. Hubungan konsentrasi-mortalitas protein Cry1Ac dan larva $H$. armigera. 
Table 3. Jumlah larva instar $1 \mathrm{H}$. armigera yang digunakan dalam uji aktivitas residu contoh tanah dari Bajeng dan Soppeng yang ditanami kapas-Bt (Bollgard) dan kapas-nonBt (Delta Pine)

\begin{tabular}{|c|c|c|c|c|c|c|c|c|}
\hline \multirow{2}{*}{ Lokasi } & \multirow{2}{*}{$\begin{array}{l}\text { Kultivar/ } \\
\text { petak }^{a}\end{array}$} & \multicolumn{7}{|c|}{ 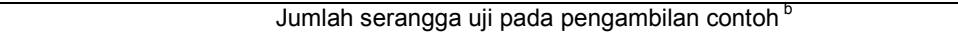 } \\
\hline & & $0 \mathrm{BST}$ & $1 \mathrm{BST}$ & $3 \mathrm{BST}$ & $5 \mathrm{BST}$ & $1 \mathrm{BSP}$ & $2 \mathrm{BSP}$ & $3 \mathrm{BSP}$ \\
\hline \multirow[t]{6}{*}{ Bajeng } & BG1 & 60 & 60 & 60 & 60 & 60 & 60 & 60 \\
\hline & BG2 & 60 & 60 & 60 & 60 & 60 & 60 & 60 \\
\hline & BG3 & $-{ }^{c}$ & 60 & 60 & 60 & 60 & 60 & 60 \\
\hline & DP1 & 60 & $-{ }^{c}$ & $-{ }^{c}$ & 60 & 60 & 60 & 60 \\
\hline & DP2 & 60 & $-{ }^{c}$ & 60 & 60 & 60 & 60 & 60 \\
\hline & DP3 & 60 & 60 & 60 & 60 & 60 & 60 & 60 \\
\hline \multirow[t]{8}{*}{ Soppeng } & BG1 & 60 & 60 & $-{ }^{c}$ & 60 & 60 & 60 & $-^{c}$ \\
\hline & BG2 & 60 & $--^{c}$ & 60 & 60 & 60 & 60 & $--^{c}$ \\
\hline & BG3 & 60 & 60 & $-^{c}$ & 60 & 60 & 60 & $--^{c}$ \\
\hline & BG4 & 60 & $--^{c}$ & $-^{c}$ & 60 & 60 & 60 & $-^{c}$ \\
\hline & DP1 & $--^{c}$ & 60 & $--^{c}$ & 60 & 60 & 60 & $--^{c}$ \\
\hline & DP2 & 60 & 60 & $-^{c}$ & 60 & 60 & 60 & $-^{c}$ \\
\hline & DP3 & $-{ }^{c}$ & $--^{c}$ & 60 & 60 & 60 & 60 & $-{ }^{c}$ \\
\hline & DP4 & 60 & $-{ }^{c}$ & 60 & 60 & 60 & 60 & $-{ }^{c}$ \\
\hline
\end{tabular}

${ }^{\mathrm{a}} \mathrm{BG}=$ Bollgard, $\mathrm{DP}=$ Delta Pine, angka 1 s.d. 4 = petak 1 s.d. 4.

${ }^{b}$ Pada semua pengujian, tidak ada larva yang mati (mortalitas $0 \%$ ).

BST = bulan setelah tanam, BSP = bulan setelah panen .

${ }^{\mathrm{C}}$ Tidak menerima kiriman contoh tanah.

Hal ini menunjukkan bahwa konsentrasi residu Cry1Ac di dalam tanah sangat rendah (pada standar kedua, Cry1Ac pada konsentrasi 0,33 x $10^{4} \mathrm{ng} / \mathrm{ml}$ mengakibatkan mortalitas larva uji sekitar 10\%, Tabel 1).

B. thuringiensis $(B t)$ merupakan mikrob tanah yang tersebar luas di berbagai bagian dunia (Glare \& O'Callaghan, 2000). Berbagai produk Bt telah digunakan secara dalam pengendalian hama sejak tahun 1960an, terutama terhadap hama ulat (Lepidoptera). Sampai saat ini belum pernah ada laporan mengenai dampak negatif yang serius akibat penggunaan Bt. Pada dosis yang efektif terhadap hama sasaran, produk $B t$ cukup aman terhadap organisme bukan sasaran termasuk serangga parasitoid dan predator serta mamalia (Glare \& O'Callaghan 2000). Pada penelitian ini, residu protein Cry1Ac di dalam tanah yang ditanami kapas-Bt Bollgard tidak mematikan hama sasaran $H$. armigera sehingga residu tersebut tidak perlu dikhawatirkan akan berdampak negatif terhadap organisme bukan sasaran di dalam tanah. Namun demikian, penelitian lebih lanjut perlu dilakukan untuk menganalisis residu Cry1Ac di tanah dalam jangka panjang (setelah beberapa kali musim tanam kapas) karena residu Cry1Ac dalam percobaan ini hanya berasal dari satu kali musim tanam.

Selain itu, penanaman kapasBt perlu dikaitkan dengan program pengelolaan resistensi karena tekanan seleksi yang tinggi akibat penanaman 
kapas-Bt secara terus-menerus pada areal yang luas dapat mengakibatkan berkembang nya ras hama sasaran yang resisten terhadap toksin $B t$ dengan cepat. Sebagai contoh, ras YHD2 Heliothis virescens yang diberi pakan yang mengandung protein Cry1Ac selama $>30$ generasi menunjukkan tingkat resistensi sekitar 10.000 kali (Jenkins 1999).

Hasil analisis tanah menunjukkan bahwa kandungan C-organik dilokasi percobaan cukup beragam. Secara umum tanah di Bajeng memiliki kandungan C-organik lebih tinggi dibandingkan dengan tanah di Soppeng. Partikel organik tanah dapat menjerap produk Bt (Possee \& King 1994). Namun dalam percobaan ini pengaruh perbedaan kandungan Corganik pada tanah Bajeng dan Soppeng terhadap aktivitas residu protein Cry1Ac dalam contoh tanah dari kedua lokasi tersebut tidak terlihat karena perlakuan dengan residu semua contoh tanah tidak mengakibatkan kemati an larva $H$. armigera (mortalitas $0 \%)$.

\section{UCAPAN TERIMAKASIH}

Penulis mengucapkan terima kasih kepada PT. Monagro Kimia atas dukungan dana penelitian dan Sdri. Endah Suhaendah atas bantuan teknisnya. Terima kasih juga disampaikan kepada Sdr. Nur Amin atas bantuan pengambilan contoh tanah

\section{DAFTAR PUSTAKA}

Baum JA, Johnson TB, Carlton BC. 1999. Bacillus thuringiensis: natural and recombinant bioinsecticide products. Di dalam: Hall FR, Menn JJ, editor. Biopesticides: Uses and Delivery. Totowa (New Jersey): Humana Press. p 189209.

Finney DJ. 1971. Probit Analysis. 3rd ed. Cambridge: Cambridge University Press.

Fitt GP, Wilson LJ. 2000. Genetic engineering in IPM: Bt cotton. Di dalam: Kennedy GG, Sutton TB, editor. Emerging Technologies for Integrated Pest Management: Concepts, Research, and Implementation. St. Paul (Minnesota): APS Press. p 108-125.

Glare TR, O’Callaghan M. 2000. Bacillus thuringiensis: Biology, Ecology and Safety. Chichester: John Wiley \& Sons.

Jenkins JN. 1999. Transgenic plants expressing toxins from Bacillus thuringiensis. Di dalam: Hall FR, Menn JJ, editor. Biopesticides: Uses and Delivery. Totowa (New Jersey): Humana Press. p 211-232.

Metcalf RL. 1982. Insecticides in pest management. Di dalam: Metcalf RL, Luckmann WH, editor. Introduction to Insect Pest Management. New York: John Wiley \& Sons. p 217-277.

Moore RF. $1985 . \quad$ Artificial diets: development and improvement. Di dalam: Singh P, Moore RF, editor. Handbook of Insect Rearing Vol 1. New York: Elsevier. p $67-75$.

Patana R. 1985. Heliothis zea/Heliothis virescens. Di dalam: Singh P, Moore $\mathrm{RF}$, editor. Handbook of Insect Rearing Vol 2. New York: Elsevier. p 329 333.

Possee RD, King LA. 1994. Molecular approaches to the design of biotic crop protection agents. Di dalam: Marshall G, Walters, editor. Molecular Biology in Crop Protection. London: Chapman \& Hall. p 68-97.

SAS Institute. 1990. SAS/STAT User's Guide, Version 6, Vol 2. 4th ed. Cary (North Carolina): SAS Institute. 
Sherrick S, Head G. 2000. General concepts, status, and potential of transgenic plants in IPM. Di dalam: Kennedy GG, Sutton TB, editor. Emerging Technologies for Integrated Pest Management: Concepts,
Research, and Implementation. St. Paul (Minnesota): APS Press. p 96-100.

Singh P. 1985. Multiple-species rearing diets. Di dalam: Singh P, Moore RF, editor. Handbook of Insect Rearing Vol 1. New York: Elsevier. p 19-40. 